\title{
Hubungan antara Kecerdasan Adversitas dengan Adaptabilitas Karier pada Karyawan BNI Cabang Rengat
}

\author{
Ifani Candra, Jimmi Bernhard, Harri Kurniawan \\ Fakultas Psikologi, Universitas Putra Indonesia "YPTK" Padang, Indonesia \\ Email: ifani_candra@yahoo.com, jimmibernhard98@gmail.com, arik_psycholog@yahoo.com
}

\begin{abstract}
This study aims to see the relationship between adversity intelligence and career adaptability of BNI employees of the Rengat branch. The independent variable in this study is adversity intelligence and the dependent variable is career adaptability. The measuring instrument used in this research is the adversity intelligence scale and the career adaptability scale. The sampling technique used in this study was saturated sampling with a total sample size of 35 employees. The validity test uses the Corrected Item-Total Correlation and the reliability test uses the Alpha Cronbach technique. The test results show the validity coefficient on the adversity intelligence scale ranges from 0.326 to 0.732 , while the reliability coefficient is 0.915 . The results of the validity coefficient on the career adaptability scale ranged from 0.349 to 0.831 , while the reliability coefficient was 0.939 . Based on the results of data analysis, the correlation coefficient is 0.368 with a significant level of correlation $(p)=0.030(<$ $0,05)$. This means that there is a significant relationship with a positive direction between adversity intelligence and career adaptability of the BNI Rengat branch. So it can be interpreted that the hypothesis in this study is accepted. The effective contribution of the adversity intelligence variable with career adaptability is as much as $14 \%$.
\end{abstract}

Keywords: adversity quotient, career adaptability, employees

\begin{abstract}
Abstrak
Penelitian ini bertujuan untuk melihat hubungan antara kecerdasan adversitas dengan adaptabilitas karier pada karyawan BNI Cabang Rengat. Variabel independent dalam penelitian ini adalah keceradasan adversitas dan variabel dependent adalah adaptabilitas karier. Alat ukur yang digunakan dalam penelitian ini adalah skala kecerdasan adversitas dan skala adaptabilitas karier. Teknik pengambilan sampel yang digunakan dalam penelitian ini adalah Sampling Jenuh dengan jumlah sampel penelitian sebanyak 35 karyawan. Uji validitas menggunakan Corrected Item-Total Correlation dan uji reliabilitas menggunakan teknik Alpha Cronbach. Hasil uji coba menunjukkan koefisien validitas pada skala kecerdasan adversitas berkisar dari 0,326 sampai dengan 0.732 , sedangkan koefisien reliabilitasnya sebesar 0,915 . Hasil koefisien validitas pada skala adaptabilitas karier berkisar dari 0,349 sampai dengan 0,831, sedangkan koefisien reliabilitasnya sebesar 0,939. Berdasarkan hasil analisis data menunjukkan besarnya koefisien korelasi sebesar 0,368 dengan taraf signifikan korelasi $(\mathrm{p})=0,030$ $(<0,05)$. Artinya ada hubungan signifikan dengan arah positif antara kecerdasan adversitas dengan adaptabilitas karier pada karyawan BNI Cabang Rengat. Sehingga dapat diartikan bahwa hipotesis dalam penelitian ini diterima. Sumbangan efektif variabel kecerdasan adversitas dengan adaptabilitas karier adalah sebanyak $14 \%$
\end{abstract}

Kata Kunci : kecerdasan adversitas, adaptabilitas karier, karyawan

\section{Pendahuluan}

Kondisi perekonomian yang terus berkembang saat ini menyebabkan sektor perbankan mempunyai kekuatan dan peluang yang besar untuk memenuhi kebutuhan keuangan masyarakat dan sektor usaha yang dimilikinya. Masyarakat dan sektor usaha sebagai pihak pengguna jasa bank yang paling berperan, pada umumnya selalu memiliki respon yang tanggap dalam berbagai bentuk layanan yang diberikan oleh masing-masing bank untuk menarik simpati nasabahnya. Bank sebagai lembaga yang sangat bergantung pada kepercayaan nasabah tentunya akan terus menyempurnakan layanannya di tengah persaingan dengan banyaknya penyedia jasa keuangan lainnya [1]. Persaingan antar perusahaan di era globalisasi semakin tajam, sehingga sumber daya manusia dituntut untuk terus-menerus mampu mengembangkan diri secara proaktif. Sumber daya manusia harus menjadi manusia-manusia pembelajar, yaitu pribadi-pribadi yang mau belajar dan bekerja keras dengan penuh semangat, sehingga potensi insaninya berkembang maksimal. Oleh karena itu, sumber daya manusia yang diperlukan pada saat ini adalah sumber daya manusia yang sanggup menguasai teknologi dengan cepat, adaptif, dan responsif terhadap perubahan- perubahan teknologi. Dalam kondisi tersebut integritas pribadi semakin penting untuk memenangkan persaingan. Persaingan antar perusahaan di era 
globalisasi semakin tajam, sehingga sumber daya manusia dituntut untuk terus-menerus mampu mengembangkan diri secara proaktif. Sumber daya manusia harus menjadi manusia-manusia pembelajar, yaitu pribadi-pribadi yang mau belajar dan bekerja keras dengan penuh semangat, sehingga potensi insaninya berkembang maksimal. Oleh karena itu, sumber daya manusia yang diperlukan pada saat ini adalah sumber daya manusia yang sanggup menguasai teknologi dengan cepat, adaptif, dan responsif terhadap perubahan- perubahan teknologi. Dalam kondisi tersebut integritas pribadi semakin penting untuk memenangkan persaingan [1]. Perubahan cepat dalam lingkungan kerja dan struktur kerja serta pengenalan teknologi baru secara terus-menerus telah menghasilkan kebutuhan akan keterampilan karier baru dan multipel yang akan mengelolanya secara efektif. Perubahan drastis dalam sifat karier ini menjadikan istilah karier tanpa batas dan karier cerdas atau protein yang lebih relevan dalam teori pengembangan karier abad ke-21. Perubahan struktur karier ini juga sejalan dengan internasionalisasi atau globalisasi dunia pasca-modern, oleh karena itu permintaan pasar tenaga kerja meningkat untuk keterampilan adaptasi karier tenaga kerja. Akibatnya, keterampilan adaptasi karier pada perusahaan intelijen karier yang didasarkan pada aspirasi pribadi dan tekad dalam ekonomi berbasis pengetahuan dengan kemunculan teknologi baru, perdagangan global, dan layanan luas yang terus-menerus adalah yang terpenting di pasar tenaga kerja dunia saat ini [2]. Penelitian ini bertujuan untuk mengetahui hubungan antara kecerdasan adversitas dengan adaptabilitas karier pada karyawan. Berbagai tokoh berusaha untuk mendefinisikan karier, salah satunya Super [3] yang menganggap karier sebagai peristiwa dalam hidup dimana pekerjaan dan berbagai peran lain dalam hidup menjadi sebuah kombinasi. Kombinasi ini menunjukkan komitmen bekerja seseorang termasuk dalam keseluruhan perkembangan dirinya. Berbagai teori berkaitan dengan karier banyak dikembangkan, seperti teori konstruksi karier, teori perkembangan karier, dan berbagai macam teori lainnya. Allison \& Cossette [3] mengungkapkan teori perkembangan karier yang dikembangkan oleh Super merupakan proses sepanjang hidup yang melibatkan faktor internal dan eksternal yang mempengaruhi karier individu. Faktor-faktor tersebut berkaitan secara langsung dengan individu sendiri, misalnya pada remaja dimana usia dan tahap perkembangan mempengaruhinya dalam merencanakan dan melakukan intropeksi diri terhadap berbagai situasi [3]. Pada perkembangan penelitiannya, Super banyak melakukan elaborasi pada perkembangan karier tersebut. Awalnya teori perkembangan karier memiliki pandangan bahwa perbedaan individu yang mengarahkannya pada pekerjaan, serta menyesuaikan individu dengan kemampuan dan minatnya. Pada 1981, Super menambah sebuah perspektif dalam teorinya, yakni tentang peran konsep diri dalam perkembangan karier, yang disebut teori perkembangan konsep diri. Dalam elaborasi ini, Super menunjukkan proses yang terlibat seperti pembentukan hingga implementasi konsep diri yang terkait didalamnya. Elaborasi terakhir pada 1990 dinamai sebagai "Life-span, Life-space theory", didalamnya ditambahkan sudut pandang konstektual yang berkaitan dengan peran sosial, dalam hal ini yaitu bagaimana seorang individu menghadapi peran pekerjaannya dan peran lainnya dalam hidupnya, menurut [3]. Menurut Savickas [4], Konsep adaptabilitas karier ini berkembang berawal dari empat segmen dalam Life-Span \& Life-Space Theory yang dikemukakan oleh Donald Super pada tahun 1981 yaitu individual differences, development, self dan context. Keempat hal ini merupakan perspektif tentang penyesuaian dalam berbagai peran kehidupan. Savickas [4] mengungkapkan kemampuan adaptasi merupakan konstruk yang sesuai untuk menjembatani keempat segmen tersebut menggeser konsep career maturity atau kematangan karier menurut Super tahun 1955. Awalnya pada tahun 1955, Super mengusung segmentasi berupa konsep kematangan karier (career maturity) dalam segmentasi tentang kehidupan. Tingkat kematangan karier menunjukkan kesiapan untuk memilih bidang pendidikan dan vokasional, yang kemudian pada 1979, ditambah dengan ide tentang adaptabilitas karier untuk melengkapi konsep kematangan karier [3]. Dalam hal ini Super meyakini bahwa dalam setiap tahap-tahap terdapat tugas-tugas yang harus dipenuhi. Selanjutnya, menurut [4] yaitu kemampuan untuk beradaptasi dengan dunia kerja mengacu pada Career Adaptability atau adaptabilitas karier. Teori konstruk karier ini mengungkapkan bahwa kemampuan adaptasi merupakan faktor penting yang memengaruhi keberhasilan individu di lingkungan pekerjaan. Kemampuan ini terlihat dari perilaku individu dalam merencanakan tindakan, mengeksplorasi situasi lingkungan, dan membuat keputusan atas informasi yang telah diperolehnya mengenai suatu karier. Savickas [3] mengungkapkan konsep adaptabilitas karier didefinisikan sebagai kesiapan untuk mengatasi tugas yang terprediksi untuk mempersiapkan dan turut berperan dalam pekerjaan, serta mampu megatasi penyesuaian yang tidak terduga yang mungkin muncul dalam perubahan dalam pekerjaan dan kondisi 
kerja. Dalam hal ini dapat pula dianggap sebagai kesiapan untuk mengatasi perubahan dalam pekerjaan dan kondisi kerja. Jadi menurut Savickas, pada saat ini kemampuan beradaptasi lebih penting dalam mengembangkan karier seseorang [4]. Pada dunia pekerjaan sebagai awal penentuan karier, dimana seseorang harus mempersiapkan diri dan berperan dalam pekerjaannya agar sesuai dengan karier yang ingin dicapai. Karena adaptabilitas karier tidak semata-mata terjadi pada dunia kerja saja, namun juga terjadi diberbagai rentang kehidupan lainnya. Misalnya pada pekerja yang mempunyai target pada posisi pekerjaannya. Pekerja harus segera mencapai target tersebut agar dengan mudahnya pekerja mampu mencapai titik karier yang diinginkannya. Proses pengambilan keputusan ini merupakan salah satu bentuk adaptabilitas karier. Savickas [3] memperkenalkan konstruk adaptabilitas karier sebagai konstruk pengganti kematangan karier. Jadi adaptabilitas ini merepresentasikan kemampuan kritikal dalam individu untuk mengarahkan proses pengambilan keputusan dalam karier dan dunia kerja. Didalam proses pembelajaran dan pengambilan keputusan terdapat komponen adaptasi. Konstruk adaptasi ini menyentuh berbagai segmentasi yang dibuat oleh Super, hal ini membuat adaptasi dapat menjadi sebuah jembatan melalui perbedaan individu, perkembangan diri, dan konstektual segmen dalam proses kehidupan manusia. Menurut Angelia, [3], dalam sudut pandang perbedaan individu dapat difokuskan pada kemampuan adaptasi dan gaya seseorang dalam suatu situasi, kemudian pada sudut pandang perkembangan memusatkan pada fungsi dan proses dari adaptasi sepanjang hidup seseorang dan pada sudut pandang kontekstual dimana individu harus beradaptasi dan bertahan ketika menghadapi berbagai situasi. Misalnya dalam dunia kerja, dimana para pekerja harus mampu beradaptasi dalam suasana pekerjaan, mungkin pada perubahan-perubahan yang terjadi pada harga pasar yang mengakitbatkan perubahan strategi yang harus dilakukan perusahaan agar target perusahaan bisa mencapai harga pasar, dengan begitu para pekerja yang mampu beradaptasi dapat mengatasi masalah yang dihadapi sehingga dapat melaksanakan pekerjaan tersebut dengan baik dan target suatu perusahaan bisa tercapai. Berdasarkan review mengenai adaptabilitas karier yang dilakukan oleh Johnston [4], variabel adaptabilitas karier telah diteliti dan memiliki hubungan yang positif dengan konstruk yang terkait dengan pengejaran tujuan dan konstruk-konstruk yang menghasilkan penyesuaian diri dan strategi coping yang positif. Beberapa konstruk tersebut adalah motivation (Poyaud et al., 2012), promotion regulatory focus (Van Vianen et al., 2012), hope and optimism (Buyukgoze-Kavas, 2014), Tenacious goal pursuit and flexible goal adjustment (Tolentino et al., 2013), dan Adversity Quotient \& Environmental Variables [5] Stolz [4] berpendapat bahwa konsep kecerdasan adversitas dibentuk berdasarkan tiga konsep ilmu pengetahuan yaitu, psikologi kognitif, neuorpsikologi dan neuroimunologi. Kecerdasan adversitas digunakan untuk mengukur respon individu terhadap kesulitan, dan untuk memprediksi individu mana yang mampu mengatasi kesulitan dan mana yang tidak. Kecerdasan adversitas juga dapat digunakan untuk memahami apakah individu mampu memenuhi potensi dan mencapai tujuannya. Selain itu, menurut Stolz, kecerdasan adversitas juga dapat digunakan untuk memprediksi individu yang akan menyerah di tengah jalan dan yang akan bertahan sampai akhir untuk tujuan mereka. Penelitian mengenai kecerdasan adversitas telah dilakukan pada berbagai macam setting, seperti pada guru, karyawan rumah sakit, manajer, psikolog, pengusaha, agen asuransi, karyawan perusahaan nonprofit, siswa dan lainnya. Penelitian-penelitian tersebut telah membuktikan bahwa kecerdasan adversitas mampu memperbaiki performa kerja, gaya kepemimpinan, resiliensi, promosi, optimisme, dan respon pada perubahan. Stoltz [6], menyatakan bahwa kecerdasan adversitas adalah kemampuan seseorang dalam menghadapi kesulitan dan tantangan hidup, mampu mengubah kesulitan menjadi peluang. Individu yang terus berjuang dalam situasi apapun akan mencapai kesuksesan. Karena setiap individu memiliki respon yang berbeda dalam merespon perubahan. Individu dengan tingkat kecerdasan adversitas nya rendah cenderung untuk menolak perubahan, biasanya mereka menghindar secara aktif menjauhi perubahan. Namun, berbanding terbalik dengan individu yang tingkat kecerdasan adversitas tinggi, individu akan menyambut perubahan dengan baik. Mereka memahami bahwa perubahan adalah kenyataan yang tidak akan dapat dihindari oleh siapapun, oleh sebab itu mereka yakin bahwa dengan adanya perubahan tersebut akan mendorong mereka untuk lebih berkembang lagi, Stolz [4]. Setiap individu memiliki tingkat kecerdasan adversitas yang berbeda, karena itu terdapat individu yang mampu bertahan sementara, individu lain gagal atau bahkan mengundurkan diri. Oleh karena itu, individu berusaha meningkatkan pengetahuan dan keterampilan untuk menutupi rasa cemas akibat persaingan yang ketat untuk mempertahankan masa depan [6]. 
Penelitian akan dilakukan di PT. BNI (Persero) Kantor Cabang Rengat Kabupaten Indragiri Hulu Riau (selanjutnya akan disebut BNI Cabang Rengat). Berdasarkan hasil wawancara yang peneliti lakukan secara online yaitu pada tanggal 15-22 Juni 2020 terhadap 15 karyawan diberbagai posisi. Dari 15 karyawan yang diwawancarai, 14 karyawan mempunyai perencanaan karier jangka pendek maupun jangka panjang untuk mencapai masa depan kariernya dan hanya 1 yang tidak mempunyai dikarenakan level kariernya sudah pada batasan kariernya. Keseluruhan karyawan siap menghadapi transisi dalam bekerja. Keseluruhan mempunyai cara tersendiri dalam mengembangkan kariernya dengan mengikuti pelatihan, bertanya pada senior atau atasan, dan terus belajar meningkatkan kemampuan pada bidangnya masing-masing. Terkait aturan kedisiplinan dalam bekerja, karyawan yang menjadi narasumber belum ada yang melanggar aturan yang berlaku. Namun karyawan kurang mampu beratnaggung jawab atas pilihan karier. Beda halnya terkait karyawan yang tidak mencoba hal baru dalam pekerjaannya sebanyak 2 karyawan dan selebihnya berusaha untuk mencoba hal baru dan beradaptasi dengan perubahan tersebut sebagai upaya peningkatan kemampuan. Karyawan cenderung kurang berani mengmbil resiko, mencari informasi dan kurang perasaan ingin tahu tentang jenjang kariernya. Karyawan juga kurang percaya diri pada keberhasilan atas pekerjaan yang dilakukan.

Berdasarkan keterangan dari narasumber, ketika dihadapkan dengan permasalahan dalam menyelesaikan pekerjaan, dari 15 karyawan, hanya 2 orang yang tetap menghadapinya sebagai tantangan baru, selebihnya menjadikan hal itu beban sehingga sedikit mengganggu produktivitas dalam bekerja dan membutuhkan dampingan dalam menyelesaikan permasalahan tersebut. Karena terlihat dari beragamnya kemampuan dalam mengatasi permasalahan tersebut yakni durasi menyelesaikan permasalahan yang terjadi seperti ada yang paling cepat satu hari hingga ada yang sampai satu bulan. Lalu tindakan yang dilakukan dalam menghadapinya juga beragam, ada yang bertanya dan konsultasi dengan senior yang sebelumnya pernah mengalami hal tersebut, menyelesaikannya dan menghadapinya langsung sendirian dengan kepala dingin. Beda halnya permasalahan tersebut mampu diidentifikasi oleh narasumber dengan memilah masalah atau menganalisa masalah dari akarnya terlebih dahulu secara runtut lalu dicari jalan keluarnya berdasarkan peraturan yang sudah berlaku agar tidak menyimpang. Terkait permasalahan pribadi, dari 15 narasumber, 3 orang yang tidak mampu membatasi kesulitannya ketika sedang bekerja sehingga pengaruh permasalahan pribadi tersebut terbawa dalam bekerja dan mengganggu produktivitas karyawan, selebihnya bersikap profesional dengan menempatkan permasalahan pribadi agar tidak dibawa dan mengganggu pikiran saat sedang bekerja dikantor. Kesulitan - kesulitan yang dihadapi karyawan dalam melakukan dan menyelesaikan pekerjaan tersebut meliputi minimnya pelatihan yang diberikan sehingga terbatasnya kapabilitas dalam menganalisa secara presisi, kurang tersedianya transportasi yang praktis ketika terdapat pekerjaan yang harus diselesaikan diluar kantor, kesulitan koordinasi dengan pihak ketiga diakrenakan SOP dan standar kerja yang berbeda-beda, kurangnya edukasi pedoman regulasi kerja dan job deskripsi yang minim terhadap karyawan.

\subsection{Adaptabilitas Karier}

Savickas [4] mengungkapkan bahwa adaptabilitas karier berhubungan kuat dengan kesejahteraan individu secara umum maupun dalam konteks profesional pekerjaan. Adaptabilitas karier juga memungkinkan individu siap mengatasi tugas perkembangan, transisi kerja dan trauma pekerjaan. Savickas [4] mengusulkan konsep adaptabilitas karier yaitu mendukung seseorang untuk mengembangkan karier dalam berbagai situasi pada usia anak-anak, remaja maupun dewasa. Savickas [7] terkait konsep adaptasi karier, yang mengacu pada kesiapan untuk menghadapi tugas-tugas yang dapat diprediksi yaitu mempersiapkan dan berpartisipasi dalam peran kerja dan dengan penyesuaian yang tidak dapat diprediksi yang disebabkan oleh perubahan dalam pekerjaan dan kondisi kerja. Savickas [7] mendefinisikan adaptabilitas karier sebagai konstruk psikososial yang menunjukkan sumber daya individu untuk mengatasi tugas perkembangan karier, transisi kerja, dan trauma pribadi. Disebut sebagai konstruk psikososial, karena sumber daya adaptabilitas karier berasal dari kekuatan regulasi diri yang bersumber dari individu pribadi dan interaksi individu dengan lingkungannya. Kekuatan tersebut digunakan untuk memecahkan masalah yang asing, kompleks dan tidak jelas yang terdapat dalam proses perkembangan, transisi pekerjaan, dan trauma yang muncul dari pekerjaan. Hal tersebut termasuk adaptasi ke transisi yang terjadi selama rentang hidup. Misalnya, transisi dari anak ke remaja, sekolah ke pekerjaan, dan dari pekerjaan ke pekerjaan. 


\subsection{Dimensi Adaptabilitas Karier}

Savickas et.al [4] merumuskan empat dimensi adaptabilitas karier yang digunakan individu untuk mengelola tugas, transisi, dan trauma dalam membangun karier. Empat dimensi tersebut adalah career concern, career control, career curiousity, dan career confidence. (a) Career Concern (Perhatian) yaitu individu akan berfokus pada pertimbangan kesempatan atau harapan dalam hidup dan perasaan optimis. Career concern menyadarkan bahwa individu untuk mengembangkan karier, menghadapi transisi kerja, dan perencanaan jangka pendek atau jangka panjang. (b) Career Control (Kontrol) yaitu cara individu dalam meregulasi diri untuk menyesuaikan dengan kebutuhan pada stuasi yang berbeda, tetapi juga dapat memengaruhi dan mengontrol lingkungan. Career control diindikasikan melalui perilaku disiplin dan mampu bertanggung jawab atas pilihan karier. (c) Career Curiousity (Keingintahuan) yaitu seseorang yang berperilaku aktif untuk mencari tahu informasi dan cara mengembagkan karier untuk meningkatkan peluang sosial. Dimensi ini ditunjukkan dalam beberapa perilaku seperti mencoba hal-hal baru, mengambil resiko, mencari informasi, dan perasaan ingin tahu.

(d) Career Confidence (Kepercayaan Diri) yaitu kemampuan individu untuk berpedoman pada pendapat dan tujuan sendiri untuk memecahkan masalah ketika menghadapi hambatan dan rintangan. Career confidence sebagai rasa kepercayaan diri pada keberhasilan dalam melakukan kegiatan yang dibutuhkan untuk mencapai karier yang dikehendakinya.

\subsection{Kecerdasan Adversitas}

Stolz [1] mendefinisikan kecerdasan adversitas sebagai kemampuan seseorang dalam mengamati kesulitan dan mengolah kesulitan tersebut dengan kecerdasan yang dimiliki sehingga menjadi sebuah tantangan untuk menyelesaikannya. Terutama dalam penggapaian sebuah tujuan, cita-cita, harapan dan yang paling penting adalah kepuasan pribadi dari hasil kerja atau aktivitas itu sendiri. Stoltz [1] mengatakan bahwa kecerdasan adversitas adalah suatu kerangka yang mampu meramalkan seberapa jauh seseorang mampu bertahan menghadapi kesulitan dan kemampuan mengatasi kesulitan tersebut dan merupakan faktor yang dapat menentukan bagaimana, jadi atau tidaknya serta sejauh mana sikap, kemampuan dan kinerja seseorang dapat terwujud di dunia dengan segala keberanian menghadapi resiko dan menuntaskan pekerjaannya.

\subsection{Dimensi Kecerdasan Adversitas}

Menurut Stoltz [1] ada empat dimensi dalam kecerdasan adversitas, yaitu (a) Control (Kendali) yaitu mengukur dua hal, yang pertama sejauh mana seseorang merasa mampu mengendalikan dan mempengaruhi sebuah situasi sulit secara positif, yang kedua sejauh mana seseorang mampu mengendalikan tanggapannya sendiri terhadap sebuah situasi sulit. (b) Origin - Ownership (Asal usul dan Pengakuan) yaitu mengukur dua hal, yang pertama sejauh mana seseorang menemukan penyebab dari suatu kesulitan dengan tepat, yang kedua sejauh mana seseorang mengakui dan bertanggung jawab atas suatu kesulitan tanpa mempedulikan penyebabnya. (c) Reach (Jangkauan) yaitu mengukur sejauh mana seseorang mampu membatasi kesulitan agar tidak menjangkau bidang kehidupanya yang lain. (d) Endurance (Daya Tahan) yaitu mengukur seberapa lama seseorang menganggap sebuah kesulitan dan penyebab kesulitan akan berlangsung.

\section{Metode Penelitian}

Jenis penelitian ini adalah kuantitatif korelasional dengan variabel penelitian menurut Sugiyono [8] Variabel Dependen, penelitian Adaptabilitas Karier (Y) dan Variabel Independen, Kecerdasan Adversitas (X). Populasi pada penelitian ini adalah karyawan BNI Cabang Rengat yang berjumlah 35 karyawan. Teknik pengambilan sampel dalam penelitian ini adalah sampling jenuh karena teknik penentuan sampel bila semua anggota populasi digunakan sebagai sampel [9] sehingga diperoleh 35 karyawan sebagai sampel penelitian.

Metode pengumupulan data yang digunakan dalam penelitian ini adalah skala model likert untuk mendapatkan data kuantitatif. Skala ini digunakan untuk mengukur sikap, pendapat, dan persepsi seseorang atau sekelompok orang tentang fenomena sosial [9]. Skala yang digunakan pada Adapatabilitas Karier dan Skala Kecerdasan Adversitas adalah model likert. Format skala yang digunakan merupakan format yang telah dimodifikasi menjadi empat alternatif jawaban yaotu SS (Sangat Sesuai), S (Sesuai), TS (Tidak Sesuai). STS (Sangat Tidak Sesuai). Aitem-aitem dalam skala ini dikelompokkan dalam item favorable dan unfavorable. Skala penelitian akan melewati berbagai 
tahap analisis yaitu uji normalitas digunakan untuk mengetahui apakah populasi data terdistribusi normal atau tidak. Uji normalitas menggunakan uji Kolmogorov-Smirnov. Uji linearitas bertujuan untuk mengetahui apakah dua variabel mempunyai hubungan yang linear atau tidak. Dua variabel dikatakan mempunyai hubungan yang linear bila signifikansi (linearity) kurang dari 0,05.

Selain itu dilakukan uji Validitas, sejauh mana ketepatan dan kecermatan suatu alat ukur dalam melakukan fungsi ukurnya [11]. Suatu item dapat dianggap memiliki daya diskriminasi yang memuaskan jika berkorelasi signifikan terhadap skor total atau jika melakukan penilaian langsung terhadap koefisien korelasi bisa digunakan batas nilai berkriteria $r_{x y} \geq 0,3$ [11]. Data skala dikatakan memiliki daya beda tinggi jika koefisien korelasi lebih besar atau sama dengan $0,3\left(r_{x y} \geq 0,3\right)$ dan sebaliknya aitem skala dikatakan gugur jika koefisien korelasi lebih kecil dari $0,3\left(\mathrm{r}_{\mathrm{xy}} \geq 0,3\right)$.

\section{Hasil dan Pembahasan}

\subsection{Hasil}

Koefisien Validitas skala Adaptabilitas Karier dengan nilai corrected item-total correlation berkisar antara 0,349 sampai dengan 0,831, dengan reabilitas 0,939, validitas skala Kecerdasan Adversitas dengan nilai corrected item-total correlation berkisar antara 0,326 sampai dengan 0.732 , dengan reabilitas 0,915. Uji normalitas dalam penelitian ini menggunakan uji Kolmogorov-Smirnov, Priyatno (2018) menyatakan bahwa data yang dinyatakan berdistribusi normal jika signifikansi (p) lebih besar dari 0,05. Berdasarkan hasil pengolahan data dengan menggunakan program IBM SPSS 21.0, Maka diperoleh hasil sebagai berikut:

Tabel 1. Uji Normalitas Skala Kecerdasan Adversitas dengan Adaptabilitas Karier

\begin{tabular}{ccccc}
\hline Variabel & N & KSZ & P & Sebaran \\
\hline Kecerdasan Adversitas & 35 & 1.154 & 0.140 & Normal \\
Adaptabilitas Karier & 35 & 0.881 & 0.526 & Normal \\
\hline
\end{tabular}

Berdasarkan uraian tabel diatas, maka diperoleh nilai signifikan pada skala Adaptabilitas Karier diperoleh dengan nilai signifikan sebesar $\mathrm{p}=0,526$ dengan $\mathrm{KSZ}=0,881$ hasil tersebut menunjukkan bahwa nilai $\mathrm{p}>0,05$ artinya sebaran berdistribusi secara normal, sedangkan skala Kecerdasan Adversitas sebesar $\mathrm{p}=0,140$ dengan $\mathrm{KSZ}=1,154$. Hasil tersebut menunjukkan bahwa nilai $\mathrm{p}>0,05$ artinya sebaran berdistribusi secara normal. Selanjutnya uji linearitas dapat dilihat pada tabel 2 berikut:

Tabel 2. Uji Linearitas Skala Kecerdasan Adversitas dengan Adaptabilitas Karier

\begin{tabular}{ccccc}
\hline $\mathbf{N}$ & Df & Mean Square & F & Sig \\
\hline 35 & 1 & 593.432 & 5.349 & 0.030 \\
\hline
\end{tabular}

Berdasarkan uraian tabel di atas, maka diperoleh nilai signifikansi sebesar $\mathrm{p}=0,030(\mathrm{p}<0,05)$. Dapat disimpulkan bahwa antara variabel Kecerdasan Adversitas dengan Adaptabilitas Karier terdapat hubungan yang linear.

Tabel 3. Hasil Uji Korelasi Skala Kecerdasan Adversitas dengan Adaptabilitas Karier

\begin{tabular}{ccccc}
\hline $\mathbf{P}$ & $(\boldsymbol{\alpha})$ & Nilai Korelasi $(\mathbf{r})$ & Rsquare & Kesimpulan \\
\hline 0.030 & 0.05 & 0.368 & 0.136 & $\begin{array}{c}\text { Sig (2-tailed) } 0,030<0,05 \text { level of } \\
\text { significant }(\boldsymbol{\alpha}), \text { berarti hipotesis } \\
\text { diterima }\end{array}$ \\
\hline
\end{tabular}

Berdasarkan uraian tabel 4 di atas, maka diperoleh koefisien korelasi antara variabel kecerdasan adversitas dengan adaptabilitas karier sebesar $(r)=0,368$ dengan taraf signifikansi $p=0,030(p<$ 0,05). Maka dapat disimpulkan bahwa ada hubungan antara kecerdasan adversitas dengan adaptabilitas karier pada karyawan BNI Cabang Rengat. Hal ini menunjukkan semakin tinggi kecerdasan adversitas maka semakin tinggi pula adaptabilitas karier pada karyawan. Begitupun sebaliknya, semakin rendah kecerdasan adversitas maka semakin rendah pula adaptabilitas karier pada karyawan. 
Tabel 4. Descriptive Statistic

\begin{tabular}{cccccc}
\hline Variable & N & Mean & Std. Deviation & Minimum & Maximum \\
\hline Kecerdasan Adversitas & 35 & 65.49 & 4.829 & 59 & 74 \\
Adaptabilitas Karier & 35 & 107.77 & 11.345 & 71 & 121 \\
\hline
\end{tabular}

Berdasarkan nilai mean empirik tersebut, maka dapat dilakukan pengelompokkan yang mengacu pada kriteria pengkategorisasian dengan tujuan menempatkan individu ke dalam kelompok-kelompok yang terpisah secara berjenjang menurut kontinum berdasarkan atribut yang diukur (Azwar, 2017).

Tabel 5. Kategorisasi Kecerdasan Adversitas dengan Adaptabilitas Karier

\begin{tabular}{ccccc}
\hline Variabel & Skor & Jumlah & Presentase (\%) & Kategori \\
\hline \multirow{3}{*}{ Kecerdasan Adversitas } & $59-60$ & 8 & $23 \%$ & Rendah \\
& $61-70$ & 22 & $63 \%$ & Sedang \\
& $71-74$ & 5 & $14 \%$ & Tinggi \\
Adaptabilitas Karier & $71-96$ & 7 & $20 \%$ & Rendah \\
& $97-119$ & 27 & $77 \%$ & Sedang \\
& $119-121$ & 1 & $3 \%$ & Tinggi \\
\hline
\end{tabular}

Berdasarkan tabel 4.10 di atas untuk variabel kecerdasan adversitas diperoleh gambaran sebesar (23\%) atau 8 karyawan dikategorikan memiliki kecerdasan adversitas yang rendah, sebesar (63\%) atau 22 karyawan dikategorikan memiliki kecerdasan adversitas yang sedang, dan sebesar (14\%) atau 5 karyawan dikategorikan memiliki kecerdasan adversitas yang tinggi.

Sedangkan untuk variabel adaptabilitas karier diperoleh gambaran sebesar (20\%) atau 7 karyawan dikategorikan memiliki adaptabilitas karier yang rendah, sebesar (77\%) atau 27 karyawan dikategorikan memiliki adaptabilitas karier yang sedang, dan sebesar (3\%) atau 1 karyawan dikategorikan memiliki adaptabilitas karier yang tinggi dari keseluruhan sampel sebanyak 35 karyawan BNI Cabang Rengat.

\subsection{Pembahasan}

Penelitian ini bertujuan untuk mengetahui hubungan antara kecerdasan adversitas dengan adaptabilitas karier pada karyawan BNI Cabang Rengat. Berdasarkan hasil uji korelasi Product Moment (Pearson) yang dilakukan dengan bantuan IBM SPSS 21.0, diperoleh nilai koefisien $(\mathrm{r})=0,368$ dengan taraf signifikan korelasi $(\mathrm{p})=0,030$, karena nilai p sig 0,030<0,05 maka hipotesis diterima. Hasil ini menunjukkan bahwa terdapat hubungan yang signifikan antara kecerdasan adversitas dengan adaptabilitas karier pada karyawan BNI Cabang Rengat dengan arah positif artinya jika kecerdasan adversitas tinggi, maka adaptabilitas karier juga tinggi. Begitu juga sebaliknya jika kecerdasan adversitas rendah, maka adaptabilitas karier juga rendah. Hubungan yang signifikan ini menunjukkan hubungan positif antara kecerdasan adversitas dengan adaptabilitas karier tergolong sedang berdasarkan pengkategorisasian interpretasi koefisien korelasi [12]

Hasil penelitian ini sesuai dengan penelitian yang dilakukan oleh [11] yang menyatakan bahwa kecerdasan adversitas adalah personal faktor yang berhubungan positif dengan adaptabilitas karier. Konsep adaptabilitas karier dapat diukur melalui pengukuran terhadap kemampuan individu untuk mengatasi kesulitan atau kecerdasan adversitas. Hal ini diperkuat dengan adanya penelitian yang dilakukan oleh [4] dengan judul "hubungan adversity quotient dengan career adaptability pada koas angkatan 2015 Fkg "X" di RSGM. Hasil penelitian menyatakan terdapat hubungan positif yang tergolong sedang antara kecerdasan adversitas dengan adaptabilitas karier. Penelitian tersebut menunjukkan bahwa semakin tinggi kecerdasan adversitas, maka semakin tinggi pula adaptabilitas karier seseorang, jika kecerdasan adversitas nya rendah, maka adaptabilitas karier seseorang juga rendah.

Berdasarkan analisa diatas terhadap 35 sampel pada karyawan BNI Cabang Rengat didapatkan kecerdasan adversitas yang berada di kategori rendah yaitu (23\%) atau 8 karyawan, kategori sedang yaitu (63\%) atau 22 karyawan dan kategori tinggi sebesar (14\%) atau 5 karyawan. Begitu juga dengan adaptabilitas karier pada pada karyawan yang berada di kategori rendah yaitu (20\%) atau 7 karyawan, kategori sedang yaitu (77\%) atau 27 karyawan, dan kategori tinggi sebesar 3\% atau 1 karyawan.

Hasil diatas menunjukkan adaptabilitas karier mayoritas karyawan berada pada kategori sedang yaitu sebesar (77\%) atau 27 karyawan. Hal ini menunjukkan bahwa karyawan cukup berusaha untuk 
beradaptasi akan karier yang sedang ditempuh. Terdapat pula karyawan yang kategori rendah yaitu sebesar (20\%) atau 7 karyawan. Menurut Savickas (dalam Husna \& Mayangsari, 2017) jika seseorang kurang memiliki adaptabilitas karier, maka orang tersebut menjadi apatis, tidak mampu memutuskan, tidak realistis, dan menahan diri untuk pencapaian kariernya. Sebaliknya terdapat pula karyawan yang kategori tinggi yaitu sebesar (3\%) atau 1 karyawan. Menurut Savickas, (dalam Alissa \& Akmal, 2019) mengatakan individu dengan adaptabilitas karier yang tinggi dapat mempersiapkan diri untuk perubahan lingkungan yang akan datang dan mengambil langkah untuk meningkatkan karier mereka di lingkungan kerja kelak. Pendapat yang sama juga dikatakan oleh O'Connell, McNeely, dan Hall (dalam Alissa \& Akmal, 2019) adaptabilitas karier dapat memberikan hasil yang positif dalam pekerjaan dan karier, seperti menyelesaikan tugas-tugas tepat pada waktunya.

Pada kecerdasan adversitas, mayoritas karyawan berada pada kategori sedang yaitu sebesar (63\%) atau 22 karyawan. Dapat dikatakan bahwa karyawan memiliki kemampuan yang cukup kuat dalam mengendalikan diri ketika menghadapi kesulitan. Karyawan tetap mampu membuat peluang dan beradaptasi pada kesulitan serta tantangan yang dihadapi. Stolz [4] menyebut kelompok yang memiliki adversity quotient pada kategori sedang dengan sebutan campers. Campers adalah kategori orang yang memilih untuk menanggapi tantangan sampai pada thap teretntu tanpa berusaha untuk mencapai tahap akhir. Setidakya mereka telah melangkah dan menanggapi tantangan yang ada di depan meeka, namun setelah mencapai tahap tertentu mereka berhenti. Mereka berhenti meskpun masih ada kesempatan untuk mengembangkan diri, mereka merasa puas atas apa yang sudah dicapainya.

Begitupun pada karyawan, memiliki harapan dan sikap optimis dalam menghadapi beban tugas ganda yang diberikan kepadanya. Karyawan menyadari meskipun beban tersebut diluar kemampuannya, tetapi mereka berusaha mengerjakannya dengan kemampuan yang mereka miliki. Orang yang berada pada kategori campers, ini sebenarnya masih memiliki potensi dan kemampuan untuk meraih kesuksesan, namun mereka seringkali menemukan banyak alasan untuk berhenti mencoba dan berusaha, [13]

Terdapat pula karyawan dalam kategori rendah yaitu sebesar (23\%) atau 8 karyawan, berada pada kategori quitters. Quitters yaitu orang yang memilih untuk keluar, menghindari kewajiban, mundur dan berhenti. Mereka yang menolak kesempatan yang diberikan oleh atasan, meeka mengabaikan, menutupi, atau meninggalkan dorongan-dorongan untuk terus menggali kompetensi yang dimilikinya, serta meninggalkan banyak hal yang ditawarkan padanya untuk terus meningkat. Sisanya karyawan pada kategori tinggi yaitu sebesar (14\%) atau 5 karyawan. dikategorikan menjadi Climbers [4], yang artinya sebutan untuk orang-orang yang membaktikan dirinya pada sebuah pendakian jenjang kesuksesan. Climbers adalah pemiki yang selalu memikirkan kemungkinan-kemungkinan, dan tidak pernah membiarkan umur, jenis kelamin, ras, cacat fisik atau mental, dan hambatan lainnya menghalanginya dalam menuju jenjang kesuksesan. Karyawan yang dalam kategori climbers ini sering merasa sangat yakin pada sesuatu yang lebih besar daripada diri mereka. Keyakinan ini membuat mereka bertahan manakala masa depan untuk sukses itu terasa menakutkan dan sulit ditaklukkan, serta harapan untuk maju mendapat tantangan hebat. Yakin bahwa segala hal bisa terlaksana, meskipun orang lain bersikap negatif dan sudah memutuskan bahwa jalannya tidak mungkin ditempuh.

Kecerdasan adversitas yang rendah merupakan salah satu faktor rendahnya adaptabilitas karier pada karyawan. Menurut [4] bahwa kecerdasan adversitas dapat mempengaruhi adaptabilitas karier. Dimensi Control, Origin \& Ownersip, Endurance memiliki hubungan positif yang signifikan dengan Career Adaptability. Hal ini menunjukkan bahwa keyakinan untuk mampu mengendalikan kesulitan, belajar dari kesalahan dan memiliki inisiatif untuk segera mengatasi kesulitan akan membantu individu untuk lebih mampu beradaptasi dengan kesulitan dan tantangan di dalam kariernya. Hal ini sesuai dengan pendapat Phoolka dan Kaur [14] menyimpulkan bahwa adversity quotient dapat berguna untuk memprediksi kinerja, ketekunan, ketahanan, umur panjang, dan respons terhadap perubahan. Jelas, kecerdasan kesulitan individu memainkan peran penting dalam kehidupan dan karier seseorang.

Berdasarkan hasil uraian dan pembahasan di atas, adapaun sumbangan efektif dari variabel kecerdasan adversitas dengan adaptabilitas karier pada karyawan adalah sebesar (14\%) sedangkan (86\%) sisanya dipengaruhi oleh faktor-faktor lain. Faktor lain yang dapat mempengaruhi adaptabilitas karier seperti orientasi tujuan (goal orientation), kepribadian (personality) dan harapan hasil (outcome expectation) Lent et al [13] 


\section{Kesimpulan}

Berdasarkan hasil pengumpulan data dan analisis data yang telah dilakukan oleh peneliti, maka dapat ditarik kesimpulan yang sekaligus merupakan jawaban dari tujuan penelitian yaitu terdapat hubungan yang signifikan antara kecerdasan adversitas dengan adaptabilitas karier pada Karyawan BNI Cabang Rengat dengan arah positif artinya jika kecerdasan adversitas tinggi, maka adaptabilitas karier juga tinggi. Begitu sebaliknya, jika kecerdasan adversitas rendah, maka adaptabilitas karier juga rendah. Adapun sumbangan efektif variabel kecerdasan adversitas terhadap adaptabilita $\mathrm{s}$ karier adalah sebesar $14 \%$ sedangkan $86 \%$ sisanya dipengaruhi oleh faktor-faktor lain.

\section{Daftar Rujukan}

[1] Dewi, Sartika. 2013. Analisis Laporan Keuangan Untuk Menilai Kinerja Keuangan Pada Pt. Bank Rakyat Indonesia (Persero) Tbk. Naskah Publikasi. Fakultas Ekonomi Dan Bisnis Universitas Muhammadiyah Surakarta

[2] Ebenehi, A. et al 2016. Predictors of Career Adaptability Skill among Higher Education Students in Nigeria. International Journal for Research in Vocational Education and Training (IJRVET). Department of Science and Technical Education, Faculty of Educational Studies, University Putra, Malaysia, 43400 Serdang, Selangor. Vol. 3, Issue 3, December 2016: 212-229

[3] Angelia, Melissa. 2012. Hubungan antara Adaptabilitas Karir dan Prestasi Akademik pada Mahasiswa Universitas Indonesia. Skripsi Dipublikasikan, Universitas Indonesia: Hal 01-89

[4] Hardianto, Yoga dan Sucihayati, Rizka Bella. 2018. Hubungan Adversity Quotient Dengan Career Adaptability Pada Koas Angkatan 2015 Fkg " $X$ " Di RSGM. Jurnal Psibernetika Fakultas Psikologi Universitas Jenderal Achmad Yani, Cimahi. Vol. 11 (2): 79-90. Oktober 2018.

[5] Tian, Yan dan Fan, Xiuzhen. (2014) Adversity Quotients, Environmental Variables And Career Adaptability In Student Nurses. Journal of Vocational Behavior. School of Nursing, Shandong University, Jinan, Shandong, P. R. China. Vol 85: Hal 251-257

[6] Amalia, Niqya Rasyida. 2013. Hubungan Antara Adversity Quotient Dengan Kematangan Karir Pada Peserta Didik Di Mandiri Enterpreneur Center (Mec) Surabaya. Jurnal Psikologi Universitas Negeri Surabaya, Volume 02 Nomor 01. 2013: Hal 01-07

[7] Kardafi, M. dan Rakhmawati, Lenny. 2017. Pengaruh Adaptabilitas Karir Terhadap Kepuasan Kerja Dengan Older Worker Age Dan Motivasi Kerja Sebagai Pemoderasi Pada Pegawai Universitas Syiah Kuala. Jurnal Ilmiah Mahasiswa Ekonomi Manajemen, Fakultas Ekonomi dan Bisnis, Unversitas Syiah Kuala. Vol. 2, No. 1, Februari 2017: 178-201

[8] Sugiyono. 2018. Metode Penelitian Kuantitatif. Bandung: Alfabeta

[9]. Sugiyono. 2014. Metode Penelitian Kuantitatif Kualitatif dan R\&D. Bandung: Alfabeta

[10] Azwar, S. 2014. Validitas dan Reliabilitas. Yogyakarta: Pustaka Belajar

[11] Venkatesh, J. dan Shivaranjani, G. 2015. Adversity Quotient Profile: An Effective Psychometric Tool To Hire The Finest Aspirant For Contemporary Organizations. Scholars Journal of Economics, Business and Management Department of Management Studies, Anna University Regional Office. Coimbatore, Navaoor, Coimbatore, 2015; 2(12):1159-1164

[12] Priyatno, Duwi. 2018. SPSS Panduan Mudah Olah Data Bagi Mahasiswa dan Umum. Yogyakarta : MediaKom

[13] Alissa, Shavira dan Akmal, Zakiah Sari. 2018. Career Decision Making Self-Efficacy Mediator Antara Dukungan Kontekstual dan Adaptabilitas Karier. Jurnal Psikologi Pendidikan \& Konseling: Jurnal Kajian Psikologi Pendidikan dan Bimbingan Konseling Universitas YARSI Jakarta Vol 5 Nomor 1 Juni 2019. Hal 01-08.

[14] Supardi, U.S. 2013. Pengaruh Adversity Qoutient Terhadap Prestasi Belajar Matematika. Jurnal Formatif Universitas Indraprasta PGRI (UNINDRA), Jakarta Selatan. Vol 3(1): Hal 61-71.

[15] Annida, N. et al 2018. Journal The Relationship Between Adversity Quotient and Career Adaptability of Internship Nursing Students. JNC - Volume 1 Nomor 1 February, 2018 